\title{
A sucessão hereditária com bens situados no exterior
}

\author{
Hereditary succession with assets located abroad
}

\section{Ana Luiza Maia Nevares*}

\section{Resumo}

\begin{abstract}
O presente artigo trata da sucessão hereditária com bens situados no exterior. Analisa-se a competência do Brasil para conhecer de bens da pessoa falecida situados em países estrangeiros, bem como a incidência de imposto de transmissão causa mortis sobre ditos bens. O texto aborda, ainda, questões pertinentes aos testamentos celebrados no exterior e com efeitos no Brasil, ponderando sobre a importância dos acordos e tratados internacionais para dar conta do crescente número de sucessões hereditárias com elementos internacionais em um mundo globalizado.
\end{abstract}

Palavras-chave: Sucessão hereditária. Bens situados no exterior. Testamento.

\section{Abstract}

This article deals with hereditary succession with assets located abroad. Brazil's competence to decide about the assets of the deceased person located in foreign countries is analyzed, as well as the incidence of taxes because of death on said assets. The text also addresses issues related to wills celebrated abroad with effect in Brazil, considering the importance of international agreements and treaties to account for the growing number of hereditary successions with international elements in the face of the globalized world.

Keywords: Inheritance. Assets located abroad. Will.

\section{Introdução}

Não são raras as vezes em que a sucessão hereditária contém elementos internacionais, seja pela nacionalidade, seja pelo domicílio do autor da herança e dos sucessores, seja pela existência de bens situados no exterior. Em primeiro lugar, deve-se determinar o foro competente para aplicar as normas sucessórias; posteriormente, define-se a lei aplicável à sucessão hereditária e, por fim, a lei que regerá a legitimação para suceder. Nesta sede, interessa discutir a primeira questão, qual seja, aquela do foro competente para aplicar as normas sucessórias. Dessa forma, abordar-se-á como o Direito brasileiro se comporta diante de um inventário processado em território nacional, mas com patrimônio situado no exterior.

O artigo 10 da Lei de Introdução às Normas do Direito Brasileiro (LINDB) determina que "a sucessão por morte ou por ausência obedece à lei do país em que domiciliado o defunto ou o desaparecido, qualquer que seja a natureza e a situação dos bens", expressando a "vocação unitária e universal da lex sucessionis" (MEINERO, 2017, p. 89), com exceção do parágrafo primeiro do referido dispositivo, que excepciona a aplicação da lei brasileira em benefício do cônjuge ou dos filhos brasileiros, ou de quem os represente, sempre que não lhes seja mais favorável a lei pessoal do de cujus, quando se tratar da sucessão de bens de estrangeiros situados no Brasil.

O sistema da unidade da sucessão pressupõe a submissão da transmissão de todos os bens do falecido a uma disciplina única, tendo como foco a pessoa do de cujus como titular de um conjunto de relações jurídicas. Assim, se durante toda a vida da pessoa o patrimônio foi considerado de forma unitária, também após o seu

\footnotetext{
* Doutora e mestre em Direito pela Universidade do Estado do Rio de Janeiro. Professora da graduação em Direito da Pontifícia Universidade Católica do Rio de Janeiro e Coordenadora da Pós-graduação lato sensu do Curso de Famílias e Sucessões da Pontifícia Universidade Católica do Rio de Janeiro. Advogada. Rio de Janeiro-RJ- Brasil. E-mail: alnevares@gmail.com.
} 
falecimento a mesma unidade deve ser observada, evitando-se a fragmentação de suas relações jurídicas, inclusive para garantir o pagamento de suas dívidas. O dito sistema se contrapõe àquele do fracionamento da sucessão, que, em atenção aos bens em si, determina a transmissão hereditária conforme o local em que os bens estão situados, distinguindo, ainda, a lei aplicável conforme sejam os bens móveis ou imóveis (MEINERO, 2017, p. 75-90).

Apesar de o art. 10 da LINDB expressar a aludida vocação do Brasil para o sistema da unidade da sucessão, constata-se que o sistema unitário só se aplica para os bens situados no Brasil, uma vez que, em virtude das regras de jurisdição internacional, não é possível que o princípio da unidade da sucessão seja exercido de forma plena, já que é necessário respeitar as leis dos países onde se situam os bens.

Com efeito, conforme dispõe o artigo 23 do Código de Processo Civil, compete à autoridade judiciária brasileira, com exclusão de qualquer outra, I - conhecer de ações relativas a imóveis situados no Brasil; II - em matéria de sucessão hereditária, proceder à confirmação de testamento particular e ao inventário e à partilha de bens situados no Brasil, ainda que o autor da herança seja de nacionalidade estrangeira ou tenha domicílio fora do território nacional e III - em divórcio, separação judicial ou dissolução de união estável, proceder à partilha de bens situados no Brasil, ainda que o titular seja de nacionalidade estrangeira ou tenha domicílio fora do território nacional. No mesmo sentido, está o art. $12, \S 1^{\circ}$, da LINB. Dessa forma, não poderia o Brasil decidir sobre bens situados fora de sua jurisdição. Assim é que, há muito, se constata obstáculo à concretização da norma da universalidade da sucessão nas relações internacionais, decorrente do "princípio geralmente aceito, de que a competência judiciária para decidir sobre bens, particularmente imóveis, é privativa dos tribunais da respectiva situação" (VALLADÃO, 2004, p. 727) ${ }^{1}$

Dessa forma, apesar do disposto no art. 10 da LINDB, é amplamente aceito na jurisprudência que o Brasil adota o princípio da pluralidade dos juízos sucessórios quando se constata a existência de bens situados no exterior, não se admitindo a competência do juízo brasileiro para decidir sobre bens situados fora do território nacional. ${ }^{2}$ Nessa esteira, cabe questionar com Fernando Pedro Meinero (2017, p. 90) se corresponde continuar classificando o Brasil como um país que adere ao sistema da unidade da sucessão, posto que se posiciona pela negativa. Em verdade, como ponderado, a unidade da sucessão dá-se internamente; no âmbito internacional, respeitam-se as regras de competência de cada país.

Não obstante o afirmado, em algumas situações, mitiga-se a competência exclusivamente brasileira em relação aos bens aqui situados, já tendo havido decisão do Supremo Tribunal Federal homologatória de sentença

Nessa direção, vale citar: "Homologação de decisão estrangeira contestada. Pedido de homologação de decisão estrangeira que decreta divórcio e efetua a partilha de bens e direitos e estabelece as responsabilidades por dívidas. Artigos 15 e 17 da Lei de Introdução às normas do Direito Brasileiro. Arts. 963 a 965 do CPC. Arts. 216-c, 216-d e 216-f do RISTJ. Requisitos. Cumprimento. Bens imóveis situados no Brasil. Inviabilidade, no ponto, de homologação da partilha. Art. 89 , I, do CPC/73. Homologação parcial. 1. Nos termos dos artigos 15 e 17 da Lei de Introdução às normas do Direito Brasileiro, 963 a 965 do Código de Processo Civil e artigos 216-C, 216-D e 216-F do Regimento Interno do Superior Tribunal de Justiça, que, atualmente, disciplinam o procedimento de homologação de sentença estrangeira, constituem requisitos indispensáveis ao deferimento da homologação, os seguintes: (i) instrução da petição inicial com o original ou cópia autenticada da decisão homologanda e de outros documentos indispensáveis; (ii) haver sido a sentença proferida por autoridade competente; (iii) terem as partes sido regularmente citadas ou haver-se legalmente verificado a revelia; (iv) ter a sentença transitado em julgado; (v) não ofender 'a soberania, a dignidade da pessoa humana e/ou ordem pública'. 6. Apenas no que diz respeito aos bens imóveis situados no Brasil, inviável a homologação da partilha efetuada pela autoridade estrangeira, pois, nos termos do art. 89, I, do CPC/73, em vigor quando da prolação da sentença estrangeira, a partilha dos bens imóveis situados no Brasil apenas pode ser feita pela autoridade judiciária brasileira, com a exclusão de qualquer outra. 7. Sentença estrangeira parcialmente homologada. STJ - HDE: 176 EX 2016/0334063-2, Relator: Ministro Benedito Gonçalves, Julgado em 15/08/2018, CE - Corte Especial, Data de Publicação: DJe 21/08/2018.

"Partilha de bens. Bens situados no estrangeiro. Pluralidade dos juízos sucessórios. Art-189, II do CPC. Partilhados os bens deixados em herança no estrangeiro, segundo a lei sucessória da situação, descabe a justiça brasileira computa-los na quota hereditária a ser partilhada, no país, em detrimento do princípio da pluralidade dos juízos sucessórios, consagrada pelo art-89, II do CPC. Recurso extraordinário conhecido e provido, em parte". STF - RE: 99230 RS, Relator: Ministro Rafael Mayer, Julgado em 22/05/198 1ª T., Data de Publicação: DJ 29-06-1984 PP-10751 EMENT VOL-01342-06 PP-01151 RTJ VOL-00110-02 pp-00750. "Processual Civil. Inventário. Requerimento para expedição de carta rogatória com o objetivo de obter informações a respeito de eventuais depósitos bancários na Suíça. Inviabilidade. Adotado no ordenamento jurídico pátrio o princípio da pluralidade de juízos sucessórios, inviável se cuidar, em inventário aqui realizado, de eventuais depósitos bancários existentes no estrangeiro". STJ - REsp: 397769 SP 2001/0195007-8, Relatora Ministra Nancy Andrighi, Julgado em 25/11/2002, $3^{a}$ T., Data de Publicação: DJ 19.12.2002 p. 362RSTJ vol. 168 p. 327. "Processo civil. Recurso especial. Inventário e partilha. Despacho com conteúdo decisório. Nulidade. [...]. O inventário e a partilha devem ser processados no lugar da situação dos bens deixados pelo falecido, não podendo o juízo brasileiro determinar a liberação de quantia depositada em instituição financeira estrangeira. Recurso especial parcialmente conhecido e provido". STJ - REsp: 510084 SP 2003/0006898-5, Relatora Ministra Nancy Andrighi, julgado em 04/08/2005, T3, DJ 05.09.2005 p. 398. 
que partilhou bem situado no Brasil, condicionando a sua execução ao recolhimento dos impostos devidos no território nacional. ${ }^{3}$ Atualmente, a posição do Superior Tribunal de Justiça é aquela segundo a qual não ofende a soberania nacional o ato estrangeiro que dispõe sobre bem situado no Brasil que seja simplesmente homologatório da vontade das partes. Nessa direção, o referido Tribunal já admitiu a homologação de sentença estrangeira que cumpriu a última vontade manifestada pelo de cujus e transmitiu bens localizados no território nacional à pessoa indicada no testamento. ${ }^{4}$

Na mesma direção, o Superior Tribunal de Justiça, tal como já ocorria com o Supremo Tribunal Federal, ${ }^{5}$ admitiu a homologação de sentença estrangeira de divórcio que dispõe sobre a partilha de bem localizado no território brasileiro, quando houve acordo prévio entre as partes em relação à divisão do referido bem, mantendo tal entendimento mesmo após a inclusão do inciso III do art. 23 do CPC. ${ }^{6}$ Vale referir, ainda, a homologação de

"Sucessão aberta no estrangeiro. Partilha Ali Processada, Compreendendo Bens Situados No Brasil. II. Homologação da Sentença Deferida, Sujeita Sua Execução Ao Pagmento Dos Tributos Devidos Pela Transmissao, E Em Conformidade Com As Leis Brasileiras". STJ - SE: 2211, Relator: Ministro Thompson Flores, Julgado em 05/12/1973, Tribunal Pleno, Data de Publicação: DJ 02/01/1974 pp-00001 EMENT VOL-00934-01 PP-00119.

4 “Homologação de Sentença Estrangeira. Partilha De Bens Imóveis Situados No Brasil. Sentença Homologanda. Ratificação De Vontade Última Registrada Em Testamento. Citação Comprovada. Concordância Expressa Dos Requeridos. Ausência De Impugnação Posterior. Caráter Definitivo Do Julgado. Art. 89 Do Código De Processo Civil E Art. 12 Da Lei De Introdução Ao Código Civil. Ofensa. Inexistência. Precedentes. Pedido De Homologação Deferido. I - O requisito da citação válida ou revelia decretada restou devidamente cumprido, pois os então requeridos foram comprovadamente cientificados da ação, não promovendo impugnação, ou, sequer, comparecendo ao juízo. O próprio decisum foi intitulado 'Sentença Declaratória à Revelia'. II - O feito caracterizou-se pela a inexistência de litígio, comprovada, primeiramente, pelo não comparecimento dos ora requeridos ao processo e não impugnação do pleito, bem como pela anuência expressa ao conteúdo do decisum e consequente não interposição de recurso face à sentença que aqui se pretende homologar. III - A anuência dos ora requeridos em relação ao decidido pela sentença homologanda, além da não interposição de recurso, confere natureza jurídica equivalente à do trânsito em julgado, para os fins perseguidos no presente feito. Precedentes do Supremo Tribunal Federal. IV - A jurisprudência do Supremo Tribunal Federal já decidiu no sentido de que compete exclusivamente à Justiça brasileira decidir sobre a partilha de bens imóveis situados no Brasil. $V$ - Tanto a Corte Suprema quanto este Superior Tribunal de Justiça já se manifestaram pela ausência de ofensa à soberania nacional e à ordem pública na sentença estrangeira que dispõe acerca de bem localizado no território brasileiro, sobre o qual tenha havido acordo entre as partes, e que tão somente ratifica o que restou pactuado. Precedentes. VI - Na hipótese dos autos, não há que se falar em ofensa ao art. 89 do Código de Processo Civil, tampouco ao art. $12, \S 1^{\circ}$ da Lei de Introdução ao Código Civil, posto que os bens situados no Brasil tiveram a sua transmissão ao primeiro requerente prevista no testamento deixado por Thomas B. Honsen e confirmada pela sentença homologanda, a qual tão somente ratificou a vontade última do testador, bem como a dos ora requeridos, o que ficou claramente evidenciado em razão da não impugnação ao decisum alienígena. VII - Pedido de homologação deferido”. STJ - SEC: 1304 US 2005/0153253-6, Relator: Ministro Gilson Dipp, Julgado em 19/12/2007, CE - Corte Especial, Data de Publicação: DJe 03/03/2008.

5 "Homologação De Sentença Estrangeira. Partilha De Imóveis Situados No Território Brasileiro. Art. 89 Do Código De Processo Civil. Soberania Nacional. Não viola a soberania nacional o provimento judicial estrangeiro que ratifica acordo, celebrado pelos antigos cônjuges, acerca de bens imóveis localizados no Brasil. Precedentes. Pedido formulado conforme o art. 216 do Regimento Interno do STF. Homologação deferida" STF - SEC: 7146 EU, Relator: Ministro Ilmar Galvão, Julgado em 12/06/2002, TRIBUNAL PLENO, Data de Publicação: DJ $02 / 08 / 2002$ PP-00062 EMENT VOL-02076-03 PP-00565.

6 "Direito Internacional Privado. Processual Civil. Sentença Estrangeira Contestada. Partilha De Bens Decretada Pela Justiça Dos Estados Unidos Da América. Arts. 15 E 17 Da Lei De Introdução Às Normas Do Direito Brasileiro. Arts. 216-C, 216-D E 216-F Do RISTJ. Pedido De Homologação De Sentença Estrangeira Deferido Parcialmente. 1. A homologação de sentenças estrangeiras pelo Poder Judiciário possui previsão na Constituição Federal de 1988 e, desde 2004, está outorgada ao Superior Tribunal de Justiça, que a realize com atenção aos ditames do art. 15 do DecretoLei n. 4.657/1942 (LINDB) e do art. 216-A e seguintes do RISTJ. 2. Nos termos dos arts. 15 e 17 da Lei de Introdução às Normas do Direito Brasileiro e dos arts 216-C, 216-D e 216-F do Regimento Interno do Superior Tribunal de Justiça, que, atualmente, disciplinam o procedimento de homologação de sentença estrangeira, constituem requisitos indispensáveis ao deferimento da homologação, os seguintes: (i) instrução da petição inicial com o original ou cópia autenticada da decisão homologanda e de outros documentos indispensáveis, devidamente traduzidos por tradutor oficial ou juramentado no Brasil e chancelados pela autoridade consular brasileira; (ii) haver sido a sentença proferida por autoridade competente; (iii) terem as partes sido regularmente citadas ou haver-se legalmente verificado a revelia; (iv) ter a sentença transitado em julgado; e (v) não ofender "a soberania, a dignidade da pessoa humana e/ou ordem pública". 3. No caso, a partilha de bens imóveis situados no Brasil, em decorrência de divórcio ou separação judicial, é competência exclusiva da Justiça brasileira, nos termos do art. 23, III, do Código de Processo Civil. Nada obstante, a jurisprudência pátria admite que a Justiça estrangeira ratifique acordos firmados pelas partes, independente do imóvel localizar-se em território brasileiro. Contudo, tal entendimento não pode se aplicar à situação em exame, em que não houve acordo, inclusive porque o réu, devidamente citado, não compareceu ao processo estrangeiro. 4. Assim, a partilha decretada no estrangeiro é válida tão somente em relação ao imóvel adquirido no Brasil em data anterior ao casamento, não Documento: 83521776 - RELATÓRIO E VOTO - Site certificado Página 5 de 6 Superior Tribunal de Justiça havendo como homologar a partilha do imóvel cuja aquisição se deu já na constância do casamento e nem, tampouco, cabe discutir a partilha dos bens situados no estrangeiro. 5. Pedido de homologação de sentença estrangeira deferido parcialmente". SEC 15.639/EX, Relator: Ministro Og Fernandes, Corte Especial, Julgado em 4/10/2017, DJe 9/10/2017 - grifo nosso. "Homologação De Sentença Estrangeira. Alemanha. Divórcio Com Acordo De Partilha De Bens. Requisitos Preenchidos. 1. Não constitui óbice à homologação de sentença estrangeira o eventual inadimplemento de obrigações dela decorrentes. O objetivo da homologação é reconhecimento da validade da decisão, a fim de que tenha eficácia no território brasileiro. 2. A mera alegação de que a sentença estrangeira dispôs sobre acordo de partilha de imóvel não obsta a homologação da sentença estrangeira. Ademais, tanto o STF quanto o STJ "já se manifestaram pela ausência de ofensa à soberania nacional e à ordem pública a sentença estrangeira que dispõe acerca de bem localizado no território brasileiro, sobre o qual tenha havido acordo entre as partes, e que tão somente ratifica o que restou pactuado" (SEC n. 1.304/US). 3. Sentença estrangeira homologada". SEC 13.469/EX, Relator: Ministro João Otávio de Noronha, Corte Especial, Julgado em 7/12/2016, DJe 16/12/2016). 
sentença estrangeira na qual foi partilhado bem imóvel situado no Brasil, tendo sido deferida a homologação por se verificar que, aqui, o resultado prático da decisão seria idêntico àquele alcançado pela decisão homologanda. ${ }^{7}$

Em que pese a pluralidade dos juízos sucessórios no plano internacional, verificam-se situações nas quais o Brasil conhece dos bens situados no exterior diante de uma sucessão hereditária. É o que ocorre, por exemplo, com a previsão do imposto de transmissão causa mortis quanto a bens situados no exterior, bem como com decisões judiciais nas quais são computados ditos bens para a realização de uma partilha.

\section{0 imposto de transmissão causa mortis e sobre doação sobre bens situados no exterior}

A Constituição da República, em seu art. 155, determina que compete aos estados e ao Distrito Federal instituir impostos sobre transmissão causa mortis e doação, de quaisquer bens ou direitos, prevendo em seu $\S 1^{\circ}$ que dito imposto compete ao estado da situação do bem, ou ao Distrito Federal, relativamente a bens imóveis e respectivos direitos, competindo, ainda, ao estado onde se processar o inventário ou arrolamento, ou tiver domicílio o doador, ou ao Distrito Federal, relativamente a bens móveis, títulos e créditos. Para as hipóteses nas quais o doador tiver domicílio ou residência no exterior ou, ainda, se o de cujus possuía bens, era residente ou domiciliado ou teve o seu inventário processado no exterior, a competência para a sua instituição será regulada por lei complementar, conforme determina o inciso III do referido artigo 155 da Constituição da República (CR, art. $155, \S 1^{\circ}, \mathrm{III}, \mathrm{a}$ e b).

Desde a promulgação da Constituição da República, jamais foi editada a lei complementar mencionada no referido art. $155, \S 1^{\circ}$, inciso III. Por tal razão, pode-se colher na jurisprudência decisões que reputaram inconstitucionais dispositivos de leis estaduais que preveem a cobrança de imposto de transmissão causa mortis sobre bens situados no exterior, como ocorreu com o estado de São Paulo. ${ }^{8}$ A matéria alcançou o Supremo Tribunal Federal, que reconheceu a repercussão geral da matéria no âmbito do RE 851-108-SP (Tema 825 da sistemática da Repercussão Geral). ${ }^{9}$

Muito embora o Supremo Tribunal Federal não tenha julgado o mérito do recurso, reconhecendo tão somente que a matéria tem sede para ser analisada pela Corte, parece que a decisão em comento animou os tribunais estaduais a reconhecerem a constitucionalidade dos dispositivos de suas leis locais quanto à matéria. Sem pretensão de esgotar uma pesquisa por todos os tribunais do Brasil, mas apenas a título de exemplo, vale registrar que assim ocorreu através de decisão proferida pelo Órgão Pleno do Tribunal de Justiça do Estado

"Homologação de sentença estrangeira. Partilha de bens efetuada em Portugal. Divórcio já homologado pelo Supremo Tribunal Federal. Imóvel situado no Brasil. Precedentes do Supremo Tribunal Federal. 1. O fato de determinado imóvel estar localizado no Brasil não impede a homologação da sentença estrangeira de partilha quanto ao mesmo bem, não ofendido o art. 89, II, do Código de Processo Civil nos termos de reiterados precedentes do Supremo Tribunal Federal. 2. Hipótese em que, apesar da sentença estrangeira não fazer menção expressa à legislação brasileira, esta foi respeitada, tendo em vista que coube $50 \%$ dos bens para cada cônjuge. 3. Homologação deferida. STJ - SEC: 878 PT 2005/0034899-9, Relator: Ministro Carlos Alberto Menezes Direito, Julgado em 18/05/2005, CE - Corte Especial, Data de Publicação: DJ 27/06/2005 p. 203.

8 'Arguição de inconstitucionalidade. A instituição de imposto sobre transmissão 'causa mortis' e doação de bens localizados no exterior deve ser feita por meio de Lei Complementar. Inteligência do art. 155, $\S 1^{\circ}$, inciso III, Alinea b, da Constituição Federal. II - O Legislador Constituinte atribuiu ao Congresso Nacional um maior debate político sobre os critérios de fixação de normas gerais de competência tributária para instituição do imposto sobre transmissão de bens - móveis/imóveis, corpóreos/incorpóreos - localizados no exterior, justamente com o intuito de evitar conflitos de competência, geradores de bitributação, entre os Estados da Federação, mantendo uniforme o sistema de tributos. III - Inconstitucionalidade da alínea 'b' do inciso II do art. 4o da Lei paulista $n^{\circ} 10.705$, de 28 de dezembro de 2000 , reconhecida. Incidente de inconstitucionalidade procedente" TJ-SP - Arguição de Inconstitucionalidade: 46042420118260000 SP 0004604-24.2011.8.26.0000, Relator: Guerrieri Rezende, Julgado em 30/03/2011, Órgão Especial, Data de Publicação: 07/04/2011.

9 "Recurso Extraordinário. Repercussão Geral. ITCMD. Bens Localizados No Exterior. Artigo 155, § 1², lii, Letras A E B, Da Constituição Federal. Lei Complementar. Normas Gerais. Competência Para Instituição. É de se definir, nas hipóteses previstas no art. 155 , $\S 1^{\circ}$, III, letras a e b, da Constituição, se, ante a omissão do legislador nacional em estabelecer as normas gerais pertinentes à competência para instituir imposto sobre transmissão causa mortis ou doação de quaisquer bens ou direitos (ITCMD), os Estados-membros podem fazer uso de sua competência legislativa plena com fulcro no art. $24, \S 3^{\circ}$, da Constituição e no art. $34, \S 3^{\circ}$, do ADCT. Decisão: O Tribunal, por unanimidade, reputou constitucional a questão. O Tribunal, por unanimidade, reconheceu a existência de repercussão geral da questão constitucional suscitada". STF - RG RE: 851108 SP - SÃO PAULO 0020249-90.2011.8.26.0032, Relator: Ministro Dias Toffoli, Julgado em 25/06/2015, Data de Publicação: DJe-163 20/08/2015. 
do Rio de Janeiro, ${ }^{10}$ por decisão proferida por Órgão fracionário do Tribunal de Justiça do Rio Grande do Sul, ${ }^{11}$ embora neste Tribunal, em decisão de 2018, tenha restado decidido o sobrestamento do feito até a decisão do Supremo Tribunal Federal, ${ }^{12}$ bem como pelo Tribunal de Justiça de Santa Catarina. ${ }^{13}$ No Tribunal de Justiça de São Paulo, tem sido mantida a posição que defende a inconstitucionalidade da cobrança. ${ }^{14}$

Apesar das recentes decisões de alguns dos nossos Tribunais decidindo pela constitucionalidade dos dispositivos de suas leis estaduais, parece que o correto deveria ser sobrestar a cobrança do imposto até o pronunciamento do Supremo Tribunal Federal. A questão é, evidentemente, controvertida, havendo divergências sobre o sentido e o alcance dos dispositivos constitucionais que regulam a matéria. Para justificar a constitucionalidade dos dispositivos das leis estaduais em questão, alega-se que os estados teriam competência para legislar no caso diante da ausência da lei complementar por força do que dispõe o art. $24,1, \S^{\circ}$ da Constituição da República, segundo o qual compete à União, aos estados e ao Distrito Federal legislar concorrentemente sobre direito tributário quanto ao estabelecimento de normas gerais, sendo certo que, inexistindo lei federal sobre normas gerais, os estados exercerão a competência legislativa plena para atender às suas peculiaridades, bem como em virtude do que dispõe o art. $34, \S \S 3^{\circ}$ e $4^{\circ}$ do Ato das Disposições Constitucionais Transitórias, segundo os quais, promulgada a Constituição, a União, os estados, o Distrito Federal e os municípios poderão editar as leis necessárias à aplicação do sistema tributário nacional nela previsto.

Ocorre que, para o estabelecimento de imposto de transmissão causa mortis e de doação para os casos em que o doador tiver domicílio ou residência no exterior ou, ainda, se o de cujus possuía bens, era residente ou

10 "Arguição de inconstitucionalidade. Direito tributário. Imposto sobre transmissão causa mortis e doação em razão de inventário de bens processado no estrangeiro. Suposta invalidade do artigo $9^{\circ}$, inciso III, da Lei Estadual $n^{\circ} 1.427 / 89$, por vulneração ao dispositivo constitucional que reclama a prévia edição de lei complementar nacional para que se opere a referida exação, sendo lei estadual inidônea para suprir a ausência daquela. O Egrégio Supremo Tribunal Federal já se manifestou pela existência de matéria constitucional e pela repercussão geral do tema, submetendo o caso à apreciação do Pleno. (RE $851108 \mathrm{RG})$. [...] a despeito do transcurso de lapso temporal superior a vinte e cinco anos após a promulgação da Constituição da República, o Congresso Nacional ainda não editou a lei complementar a que alude o seu artigo 155 , $\S$ $1^{\circ}$, inciso III. Ocorre que essa injustificável omissão legislativa, como parece intuitivo, não pode ter o condão de comprometer a efetividade da vontade do Poder Constituinte Originário, que inequivocamente se direcionou no sentido de que a transmissão causa mortis de bens situados no exterior - assim como se dá com os bens situados no Brasil - seja suscetível de exação. ¿ (Parecer do Ministério Público). O incidente processual da arguição de inconstitucionalidade, sob o fundamento de assegurar a uniformização dos entendimentos dos diversos órgãos e juízes de tribunal sobre a constitucionalidade dos atos normativos do Poder Público, constitui poderoso e até mesmo correntio instrumento da Hermenêutica na prática forense, garantindo a aplicabilidade das normas que gozam de supremacia sobre as demais normas do sistema jurídico. O resultado do incidente não é simplesmente afastar ou não a eficácia da norma, mas, principalmente, a essa norma inferior conferir eficácia pelo seu reconhecimento de compatibilidade com a Lei Maior ou mesmo lhe conferir uma interpretação que seja conforme a Constituição. Transição do controle de constitucionalidade incidental para os efeitos genéricos, em www.nagib.net. Caráter bifrontal dos efeitos da decisão do Pleno: normativo e jurisdicional. Improcedência da arguição. Declaração de constitucionalidade da norma ora impugnada". TJ-RJ - Arguição De Inconstitucionalidade: 01891882420118190001 Rio De Janeiro Tribunal De Justica, Relator: Nagib Slaibi Filho, Julgado em 01/02/2016, OE - Secretaria do Tribunal Pleno e Orgão Especial, Data de Publicação: 11/02/2016.

11 "Apelação Cível. Mandado De Segurança. Inventário. ITCD Mortis Causa. Bens Móveis No Exterior (Quotas Em Empresa Localizada Na Comunidade Das Bahamas). Deliberação Do Stf Pela Repercussão Geral (Tema 825). 1. O art. 155, $\S 1^{\circ}$, III, alínea b, da CF, estabelece que se o de cujus deixar bens no exterior, a competência dos Estados e DF para instituir ITCD mortis causa será regulada em lei complementar, a qual inexiste, motivo por que, enquanto inexistir, os Estados exercem competência legislativa plena (CF, art. 24 , I, §§ $2^{\circ}$ e $3^{\circ}$ ), conforme orientação do STF pela repercussão geral (RE 851108, em 25-6-2015 - TEMA 825). 2. Portanto, no Rio Grande do Sul é devido o ITCD mortis causa por bens móveis no exterior (Lei-RS 8.821/89, art. $3^{\circ}$, II). 3. Apelação desprovida" Apelação Cível N 70071581847 , Primeira Câmara Cível, Tribunal de Justiça do RS, Relator: Irineu Mariani, Julgado em 13/09/2017.

12 Recurso Extraordinário. Repercussão Geral. Tema 825 do STF. ITCD. Incidência Sobre Bens Móveis No Exterior. Sobrestamento. Recurso Extraordinário $n^{\circ}$ 70076247576, Primeira Vice-Presidência, Tribunal de Justiça do RS, Relator: Maria Isabel de Azevedo Souza, Julgado em $12 / 04 / 2018$.

13 “Apelação Cível. Mandado De Segurança. Tributário. Inconstitucionalidade Da Lei Estadual N. 13.136/04. Imposto Sobre Transmissão “Causa Mortis” E Doação (ITCMD). Doador Residente No Exterior. Pretensa Inexigibilidade Do Tributo Por Ausência De Lei Complementar Federal. Insubsistência. Omissão Legislativa Que Não Obsta A Imposição Tributária. Competência Estadual Plena Para Editar Norma Regulamentadora Até O Advento Da Legislação Complementar Federal. Orientação Da Corte Suprema. Precedentes Desta Corte E Do Superior Tribunal De Justiça. Ausência De Direito Líquido E Certo. Decisão Mantida. Recurso Desprovido. No silêncio do Código Tributário Nacional em relação à incidência do Imposto de Transmissão Causa Mortis e Doações sobre a transmissão de bens móveis e intangíveis, certo é que a matéria, frente ao previsto no art. 155, inc. I, da Constituição Federal, ficou a cargo dos Estados-membros e do Distrito Federal, cuja competência será mantida até o advento de lei complementar sobre o tema (ACMS n. 2009.024358-0, rel. Des. Jaime Ramos, j. 5.5.2011) [...]" TJSC, ACMS n. 2012.070606-8, Relator: Desembargador Paulo Henrique Moritz Martins da Silva, Julgado em 19/03/2013.

14 "APELAÇÃO - Mandado de Segurança - Aquisição de bens do exterior por força da transmissão causa mortis - ITCMD - Artigo 155, §1 ${ }^{\circ}$ II, da Constituição Federal - Necessidade de lei complementar para a instituição - Inconstitucionalidade do artigo $4^{\circ}$, II, b, da Lei Estadual $n^{\circ} 10.705 / 00$ já reconhecida pelo Órgão Especial - Sentença concessiva da ordem mantida - Recurso desprovido". TJ - SP - APL: 10090351220178260053 SP 1009035-12.2017.8.26.0053, Relator: Ana Liarte, 10/09/2018, 4ª Câmara de Direito Público, Data de Publicação: 13/09/2018. Mandado de segurança preventivo. ITCMD. Incidência dobre a transmissão de bens localizados no exterior. Impossibilidade de tributação. Ausência de Lei Complementar na forma do artigo 155, $§ 1^{\circ}$, III, da Constituição Federal. Lei Estadual $n^{\circ} 10.705 / 00$ declarada inconstitucional pelo Órgão Especial desta C. Corte. Sentença concessiva da segurança mantida. Recursos improvidos (TJ - SP - APL: 10004044520188260053, Relator Luis Fernando Camargo De Barros Vidal, Julgado em 27/08/2018, $4^{\text {a }}$ Câmara de Direito Público, Data de Publicação: 29/08/2018). 
domiciliado ou teve o seu inventário processado no exterior, optou a Constituição da República por um sistema através do qual a normativa seja emanada através de uma lei de caráter nacional, ou seja, uma lei que se aplica a todos os entes da Federação - União, Estados e Municípios, sendo, portanto, uma lei complementar. Esta foi a opção "para regular, de maneira uniforme, tributo, que poderia ser desfigurado por disciplina normativa diferenciada emanada das demais entidades federativas" (MARTINS, 2004, p.118), bem aduzindo Ives Gandra Martins que, em nenhum momento, o Constituinte admitiu que "a lei complementar de caráter nacional pudesse ser substituída por 27 leis estaduais" a regular a matéria (MARTINS, 2004, p. 122).

Nycolas Martins Colucci e Diogo Ferraz (2014, p. 208) apresentam o seguinte exemplo, a saber: imagine-se "uma transmissão causa mortis de bens móveis situados no Estado de São Paulo, cujo inventário é processado no exterior e os herdeiros são residentes no Rio de Janeiro. Diante de tal situação fática, em tese, a cobrança de tributos poderia ser feita por ambos os Estados, isto é, tanto o Estado onde estão localizados os bens (São Paulo), como o Estado de residência dos herdeiros (Rio de Janeiro), a depender do elemento de conexão eleito por cada Estado para ensejar a tributação pelo imposto causa mortis". Seguindo a previsão do disposto no art. 146, I, da Constituição da República, cabe à lei complementar justamente dispor sobre conflitos de competência, em matéria tributária, entre a União, os Estados, o Distrito Federal e os Municípios.

E não é só. Se os Tribunais Brasileiros, em regra, se comportam com indiferença em relação ao patrimônio do falecido situado no exterior, reconhecendo a pluralidade dos juízos sucessórios e, dessa forma, afirmando que o Brasil não tem competência para decidir sobre a transmissão sucessória de bens situados fora do Brasil, interpretando a contrario sensu a norma do artigo 23 do CPC, por qual razão lhe assistiria legitimidade para cobrar imposto de transmissão causa mortis sobre ditos bens? Ora, o referido tributo já será pago no país onde se situa o bem e, evidentemente, se aqui também é cobrado imposto da mesma natureza, estar-se-á diante de evidente caso de bitributação, que não se poderia admitir.

As questões relacionadas à bitributação não são desconhecidas no âmbito internacional. É o que ocorre, por exemplo, quanto ao imposto de renda, em relação ao qual há pactos em que os signatários admitem a dedução do imposto sobre a renda devido no país, daquele pago no país signatário do pacto, para não cumular incidências (MARTINS, 2004, p. 124). O cuidado com a análise dos pactos internacionais de bitributação dos quais o Brasil é signatário só viria através de uma lei complementar, sendo mais uma razão pela determinação da Constituição da República quanto à previsão da instituição do imposto em questão pela via da legislação complementar.

O art. 24, I, $\S^{\circ}$ da Constituição da República c/c o art. $34, \S \S 3^{\circ}$ e $4^{\circ}$ do Ato das Disposições Constitucionais Transitórias, admitem que os entes federativos legislem sobre normas gerais à aplicação do sistema tributário nacional, o que não é o caso em questão. Diante do que dispõe o art. 146, inciso III, da Constituição da República, verifica-se o que são normas gerais em matéria tributária. Nenhuma delas se refere à delimitação da competência tributária, ou seja, ao poder concedido a cada ente para a instituição dos seus tributos. Todas dizem respeito à estruturação dos tributos que Ihes foram anteriormente concedidos (COLUCCI, 2014, p. 116). Dessa forma, espera-se que o RE atualmente em curso no Supremo Tribunal Federal seja julgado improcedente, assistindo razão ao então Procurador-Geral de Justiça, Rodrigo Janot Monteiro de Barros, em seu parecer contrário ao provimento do RE, in verbis:

Tal situação explica-se facilmente pelo contexto envolvido: trata-se não só das tensões naturais resultante do fracionamento de soberania na Federação, mas também do conflito com outras soberanias. A conexão internacional das aludidas hipóteses de incidência conduz à necessidade de uma diferenciada lei nacional, preocupada em lidar com as áreas cinzentas de incidência da exação nos âmbitos interno e externo. Assim, não podem os Estados valer-se de suposta competência plena nessas situações, sob pena de autorizar-se fragmentação legislativa em contexto já reconhecido pela Constituição como complexo, indo de encontro ao sistema tributário nela delineado.

\section{Cômputo dos bens situados no exterior no monte hereditário no Brasil}

Além da cobrança do imposto de transmissão causa mortis, não é incomum verificar na jurisprudência situações em que, apesar da pluralidade dos juízos sucessórios e da incompetência da justiça brasileira para 
conhecer de bens situados no exterior, estes são considerados para alcançar a igualdade de herdeiros ou cônjuges em partilhas de bens ${ }^{15}$. Nessa direção, apesar de os ditos bens se encontrarem no exterior e não ter o Brasil competência para conhecê-los, são computados nas partilhas, sendo imputados em pagamentos de herdeiros ou cônjuges para fins de equilíbrio entre os quinhões conforme os bens que estão aqui situados. Argumenta-se que o cômputo de bens situados no exterior para fins de partilha estaria em consonância com o disposto no art. 10 da LINDB, no sentido da unidade da sucessão. Esse mecanismo é defendido por André de Carvalho Ramos (2016, p. 322), que assim se posiciona:

Esses últimos precedentes citados demonstram que é possível conciliar a regra de fixação da jurisdição cível brasileira do novo CPC com a escolha do direito material determinada pela LINDB, que, em muitos casos, impõe a igualdade entre os sucessores. No caso de bens situados no exterior, o uso da técnica da compensação faz com que o DIPr brasileiro não seja esvaziado: se a lei do domicílio do de cujus determinar, por exemplo, a igualdade entre os herdeiros, os bens situados no exterior podem ser valorados e incluídos no rateio do patrimônio perante o juízo do inventário do Brasil, em desfavor do herdeiro que detém tais bens no exterior.

Com isso, combate-se o argumento da inexequibilidade da decisão da Justiça brasileira sobre bens situados no exterior (a "faca que não corta", no estilo irônico de Valladão), uma vez que não é necessário que os bens fora do Brasil sejam alcançados pela Justiça brasileira, mas tão somente que sejam considerados seus valores, prestigiando-se o DIPr criado pela lei ou pelos tratados ratificados pelo Brasil.

No entanto, como acima exposto, essa não é a posição que prevalece na jurisprudência brasileira. Assim, diante da pluralidade dos juízos sucessórios, a compensação seria imprópria e não corresponderia à normativa de competência internacional. ${ }^{16}$ De fato, o estabelecimento de uma compensação tout court na sucessão hereditária enseja problemas que podem ser de difícil solução, admitindo ampla discricionariedade do juiz. O primeiro deles

15 “Direitos Internacional Privado E Civil. Partilha De Bens. Separação De Casal Domiciliado No Brasil. Regime Da Comunhão Universal De Bens. Aplicabilidade Do Direito Brasileiro Vigente Na Data Da Celebração Do Casamento. Comunicabilidade De Todos Os Bens Persentes E Futuros Com Exceção Dos Gravados Com Incomunicabilidade. Bens Localizados No Brasil E No Libano. Bens No Estrangeiro Herdados Pela Mulher De Pessoa De Nacionalidade Libanesa Domiciliada No Brasil. Aplicabilidade Do Direito Brasileiro Das Sucessões. Inexistência De Gravame Formal Instituído Pelo De Cujus. Direito Do Varão À Meação Dos Bens Herdados Pela Esposa No Libano. Recurso Desacolhido. I - Tratando-se de casal domiciliado no Brasil, há que aplicar-se o direito brasileiro vigente na data da celebração do casamento, 11.7.1970, quanto ao regime de bens, nos termos do art. $7^{\circ}-\S 4^{\circ}$ da Lei de Introdução. II - O regime de bens do casamento em questão é o da comunhão universal de bens, com os contornos dados à época pela legislação nacional aplicável, segundo a qual, nos termos do art. 262 do Código Civil, importava "a comunicação de todos os bens presentes e futuros dos cônjuges e suas dívidas passivas", excetuando-se dessa universalidade, segundo o art. 263-II e XI do mesmo Código "os bens doados ou legados com a cláusula de incomunicabilidade e os sub-rogados em seu lugar", bem como "os bens da herança necessária, a que se impuser a cláusula de incomunicabilidade". III - Tratando-se da sucessão de pessoa de nacionalidade libanesa domiciliada no Brasil, aplica-se à espécie o art. 10, caput, da Lei de Introdução, segundo o qual "a sucessão por morte ou por ausência obedece à lei em que era domiciliado o defunto ou desaparecido, qualquer que seja a natureza e a situação dos bens". IV - Não há incomunicabilidade dos bens da herança em tela, sendo certo que no Brasil os bens da herança somente comportam incomunicabilidade quando expressa e formalmente constituído esse gravame pelo de cujus, nos termos dos arts. 1.676, 1.677 e 1.723 do Código Civil, complementados por dispositivos constantes da Lei de Registros Públicos. V - Não há como afastar o direito do recorrido à meação incidente sobre os bens herdados de sua mãe pela recorrente, na constância do casamento sob o regime da comunhão universal de bens, os que se encontram no Brasil e os localizados no Líbano, não ocorrendo a ofensa ao art. 263, do Código Civil, apontada pela recorrente, uma vez inexistente a incomunicabilidade dos bens herdados pela recorrente no Líbano. VII - O art. 89-II, CPC, contém disposição aplicável à competência para o processamento do inventário e partilha, quando existentes bens localizados no Brasil e no estrangeiro, não conduzindo, todavia, à supressão do direito material garantido ao cônjuge pelo regime de comunhão universal de bens do casamento, especialmente porque não atingido esse regime na espécie por qualquer obstáculo da legislação sucessória aplicável. VIII - Impõe-se a conclusão de que a partilha seja realizada sobre os bens do casal existentes no Brasil, sem desprezar, no entanto, o valor dos bens localizados no Líbano, de maneira a operar a equalização das cotas patrimoniais, em obediência à legislação que rege a espécie, que não exclui da comunhão os bens localizados no Líbano e herdados pela recorrente, segundo as regras brasileiras de sucessão hereditária" STJ - REsp: 275985 SP 2000/0089891-0, Relator: Ministro SÁLVIO DE FIGUEIREDO TEIXEIRA, Julgado em 17/06/2003, T4 - Quarta Turma, Data De Publicação: DJ 13/10/2003 P. 366. "Recurso Especial. Civil e Processual Civil. Direito Internacional Privado. Ação de Divórcio. Partilha de Bens Adquiridos na Constância da União e, após, o Casamento. Bens Localizados no Exterior. Competência a Justiça Brasileira para a Definição dos Direitos e Obrigações Relativos ao Desfazimento da Instituição da União e do Casamento. Observância da Legislação Pátria quanto à Partilha Igualitária de Bens sob pena de divisão injusta e contrária às regras de Direito de Família do Brasil. Reconhecimento da Possibilidade de Equalização dos Bens. Precedente. Dissídio Jurisprudencial. Ausência de Similitude. Recurso Especial a que se Nega Provimento". Lê-se no voto: "O reconhecimento de direitos e obrigações relativos ao casamento, com apoio em normas de direito material a ordenar a divisão equalitária entre os cônjuges do patrimônio adquirido na constância da união não exige que os bens móveis e imóveis existentes fora do Brasil sejam alcançados, pela Justiça Brasileira, a um dos contendores, apenas a consideração dos seus valores para fins da propalada equalização". STJ - REsp: 1410958 RS 2011/0244043-3, Relator Min. Paulo De Tarso Sanseverino, Julgado em 22/04/2014, T3, Data de Publicação: DJe 27/05/2014.

16 "Processual Civil. Inventário. Requerimento para expedição de carta rogatória com o objetivo de obter informações a respeito de eventuais depósitos bancários na Suíça. Inviabilidade. - Adotado no ordenamento jurídico pátrio o princípio da pluralidade de juízos sucessórios, inviável se cuidar, em inventário aqui realizado, de eventuais depósitos bancários existentes no estrangeiro". STJ - REsp 397769 SP 2001/0195007-8, Relator: Ministra Nancy Andrighi, Julgado em 25/11/2002, T3, DJ 19/12/2002 p. 362RSTJ vol. 168 p. 327. 
seria a questão da valoração do bem no exterior e a sua prova, uma vez que, por mais que seja possível se valer da declaração de Imposto de Renda do falecido, por exemplo, esta representa um retrato de um momento que raramente representa o óbito, sem contar no fato da sabida desvalorização dos bens ali indicados.

A segunda questão é ponderar se, ao se computar, numa partilha sucessória, bens situados no exterior que tenham sido atribuídos a um só dos herdeiros, por exemplo, devem os ditos bens serem somados no monte como um todo e atribuídos a título de disponível ao herdeiro beneficiado, interpretando a vontade do de cujus, que ao beneficiar apenas um dos filhos no exterior pretendeu the contemplar com maior patrimônio e, assim, com sua cota disponível, ou se referidos bens devem ser imputados na legítima do herdeiro beneficiado no exterior. Além disso, nessa compensação, deve a justiça brasileira levar em conta a legislação sucessória que informou a distribuição dos bens realizada no exterior ou apenas avaliar como restou dividido o patrimônio no final? Realmente, pode ser que no país estrangeiro determinado ativo tenha integrado patrimônio comum entre cônjuges e o mesmo não ocorra no Brasil, por exemplo, em virtude de regras de conexão internacional.

Outra reflexão é quanto aos impostos pagos na sucessão no exterior. Ditos tributos também deverão ser contabilizados e compensados? Em que proporção? E eventual testamento celebrado aqui no Brasil, como seria interpretado diante da compensação?

Além disso, é possível não haver bens no Brasil a serem compensados ou, ainda, não restarem aqui bens suficientes para a composição dos quinhões uma vez realizada a compensação. Nessas hipóteses, restará constituído um crédito de difícil satisfação, baseado em premissa duvidosa, já que o Brasil não tem jurisdição sobre bens situados no exterior. A compensação, portanto, pode parecer simples e viável em primeira vista, mas pode, por outro lado, ensejar diversos questionamentos de difícil solução, ensejando insegurança para as partes envolvidas.

Dessa forma, é preciso analisar a questão com muita cautela. Sem examinar o caso concreto, não se pode dizer, a priori, que decisões referentes à partilha de bens que considerem patrimônio no exterior seriam contrárias às regras de competência internacional. Isto porque a decisão brasileira que compute os referidos bens situados no exterior não será executada no estrangeiro, mas em território nacional, apenas contabilizando o aludido patrimônio. Já em 1952, Haroldo Valladão (2016, p. 746), ao discorrer sobre a unidade ou pluralidade da sucessão e do inventário e partilha no Direito Internacional Privado, quando concluiu que a soberania de cada país quanto às regras de competência em relação aos bens situados em seu território impedia a realização do princípio da unidade e, assim, que seria necessário que em cada país onde estivessem situados bens da pessoa falecida fosse realizado um inventário, assim se manifestou:

Se todos os herdeiros são maiores e capazes e se estão de acordo, cabível, no caso, transação, é possível a unidade sucessória com um só inventário e partilha, em certo Estado, abrangendo bens sitos noutros países, no que não fôr contrário às normas de ordem pública de tais países, sôbre sucessão, inventário e partilha, etc.

A transferência de tais bens nesses países ficará, entretanto, sugeita alí às respectivas exigências fiscais, particularmente no que concerne ao impôsto de transmissão 'causa-mortis', baseado de regra noutra divisão entre os herdeiros ou seja naquela estabelecida pelo direito civil do país coletor do imposto.

Euclides de Oliveira e Sebastião Amorim (2016, p. 469-470) comungam da mesma opinião, argumentando que "também se pode incluir na partilha feita no Brasil o valor de bens que já tenham sido atribuídos a uma das partes, valendo como imputação de pagamento do respectivo quinhão, para equilíbrio na divisão dos bens". Nesse sentido, decidiu o Tribunal de Justiça do Estado de São Paulo:

INVENTÁRIO - Autora da herança, que possui bens no Brasil e no Exterior. Na partilha, segundo o direito brasileiro, cumpre considerar o valor dos bens situados lá fora, para cômputo da legítima das herdeiras necessárias. Art. 89, II, do Código de Processo Civil. Se a autora da herança possui bens no Brasil e no Exterior, na partilha realizada segundo o direito brasileiro, será força considerar o valor o patrimônio alienígena para cômputo da legítima das herdeiras necessárias, sem que isso implique violação do art. 89, II, do Código de Processo Civil (TJSP - $4^{\text {a }}$ CDPriv. - Al 369.085.4/3-00/SP - Rel. Des. Carlos Biasotti - DOESP 24.02.2005 - v.u.) (MADALENO, 2005, p. 223). 
No caso em questão, instaurado o inventário, os interessados apresentaram partilha amigável que levava em conta bens do autor da herança situados no exterior. O juiz de primeiro grau determinou a retificação da partilha para a exclusão dos referidos bens situados em país estrangeiro ao argumento de que não cabiam à jurisdição brasileira e, assim, os herdeiros recorreram da decisão alegando que não pretendiam que o Brasil dispusesse sobre o destino dos bens, mas apenas que os contabilizasse para efeitos daquela partilha amigável apresentada. O Tribunal de Justiça do Estado de São Paulo acolheu a pretensão dos sucessores.

De igual forma deve ocorrer quando o autor da herança assim dispõe em seu ato de última vontade, determinando o cômputo de todos os seus bens, onde quer que se situem, para a divisão entre os seus sucessores. Não raro, as pessoas, em seu planejamento sucessório, pretendem distribuir o patrimônio entre os seus herdeiros, preservando a igualdade, mas considerando todo o patrimônio deixado, quer sejam bens situados no Brasil, quer sejam aqueles situados no exterior. Sem dúvida, ambas as hipóteses estariam em consonância com a unidade da sucessão, disposta no art. 10 da LINBD.

Além das hipóteses de acordo entre os herdeiros e de previsão testamentária quanto ao cômputo dos bens situados em país estrangeiro para fins de partilha no Brasil, deve-se registrar que repulsa a ordem jurídica que uma pessoa transfira todos os seus bens para o exterior ou a parte mais valiosa deles, privilegiando certos herdeiros em detrimento de outros, em clara violação aos preceitos da legislação brasileira sucessória. Assim, se restar caracterizado que o envio de bens para o exterior foi realizado com desvio de finalidade, com o claro e puro objetivo de fraudar a lei sucessória brasileira, justificar-se-ão mecanismos de proteção aos herdeiros que foram prejudicados, como a compensação com os bens situados no Brasil. Na mesma direção, se comprovado que bens situados no Brasil foram incorporados em estruturas societárias sediadas no exterior, restando claro que o autor da herança se valeu dos referidos expedientes para violar a legítima dos herdeiros necessários ou os direitos do cônjuge ou companheiro sobrevivente, poder-se-á aplicar a desconsideração inversa da personalidade jurídica daquela empresa, incluindo no monte a ser inventariado no Brasil os bens situados em território nacional.

Nessa direção, aos interessados devem ser garantidas medidas de salvaguarda de seus direitos, como a determinação para exibição de documentos ou afins sobre bens da pessoa falecida situados no exterior, ${ }^{17}$ bem como outras que poderiam ser cumpridas pela própria autoridade do país onde se situa o bem, como a expedição de ofício para conhecer saldos bancários ou mesmo uma autorização para a obtenção de documentos, tendo sido essa última hipótese julgada pelo Superior Tribunal de Justiça em caso no qual três herdeiros requereram a expedição de alvará para movimentação das contas do falecido no Credit Suisse Banking e para a abertura do cofre e retirada de toda a documentação lá existente, tendo o referido Tribunal cassado a determinação de expedição do alvará, no entanto mantendo a autorização para que os herdeiros obtivessem os documentos contidos no cofre existente no Credit Suisse Banking em nome do falecido. ${ }^{18}$

\section{Testamento celebrado no exterior com efeito no Brasil}

Nesta sede, vale um registro sobre testamentos celebrados no exterior e sua eficácia em território brasileiro. Os atos de última vontade devem ser analisados sob o ponto de vista da sua forma, da capacidade do testador e, ainda, sob o ponto de vista da sua substância. Em relação à forma, ou seja, à validade extrínseca do ato, deve ser aplicada a lei do local em que o testamento foi realizado, ou seja, locus regit actum. Já quanto à capacidade

17 “Apelação cível. Ação de exibição de documentos. Requerente que teve reconhecida judicialmente sua união estável com o de cujus, cujo espólio é integrado, dentre outros bens, por investimentos em sociedade sediada na Holanda, denominada Genesis Engineering C. V. Alegação da autora de que o réu, filho do autor da herança, vem ocultando informações e documentos sobre a empresa Genesis, impossibilitando a realização da sobrepartilha. Sentença que rejeitou as preliminares de afastamento da jurisdição brasileira e de ilegitimidade ativa ad causam. No mérito, julgou procedente o pedido para determinar a exibição dos documentos apontados pela autora, no prazo de 30 dias, sob pena de multa diária no valor de \$ 500,00. Irresignação do réu insistindo no afastamento da jurisdição brasileira. Rejeição. Incidência do art. 21, i, do CPC/15. Réu domiciliado no brasil. Preliminar de cerceamento de defesa que se afasta. Prova coligida aos autos que se revela suficiente ao deslinde da questão, não se exigindo a produção de outras provas além das já apresentadas pelas partes. Mérito. Apelante detentor da integralidade dos ativos da sociedade holandesa Genesis. Posição que o obriga a apresentar a documentação solicitada. Art. 399, I, CPC. Desprovimento do recurso". TJRJ, $2^{a}$ CC, Apelação Cível nº 0432411-67.2016.8.19.0001, Rel. Des. Luiz roldão de Freitas Gomes Filho, julgado em 18.04.2018.

18 Vide STJ - REsp: 510084 SP 2003/0006898-5, Relatora Ministra Nancy Andrighi, Julgado em 04/08/2005, T3, Data de Publicação: DJ 05/09/2005 p. 398 , citado na nota 2 acima. 
do testador, trata-se de questão relativa ao seu estatuto pessoal e, portanto, aplica-se o disposto no art. $7^{\circ}$ da LINBD, sendo a aludida capacidade regulada pela lei do domicílio do testador no momento em que realizou o testamento. Quanto às disposições testamentárias, ou seja, quanto à substância do ato, aplica-se à lei reguladora da sucessão, que é aquela do domicílio do de cujus, consoante o art. 10 da LINDB. De fato, esta última regulará a eficácia das disposições testamentárias.

O desafio nessa análise é aquele da qualificação no Direito Internacional Privado, uma vez que "o que um Estado considera como sendo questão de forma, para outro pode ser questão de substância" (ARAUJO, 2018, p. 320). Há muitas teorias que explicam a qualificação no Direito Internacional Privado. Segundo Jacob Dolinger (2014, p. 403), o Direito Internacional Privado brasileiro aplica a lex fori, ou seja, a lei local para a qualificação em geral, com exceção dos bens e contratos, e rejeita qualquer reenvio indicado pela lei estrangeira (LINDB, art. 16). Assim, a qualificação é o ponto de partida do processo conflitual e deve se reger pela lei do foro, pois, conforme a classificação que for dada, haverá ou não a aplicação da lei estrangeira, conforme seja a determinação da normativa do Direito Internacional Privado (DOLINGER, 2014, p. 394). Assim, verificando o juiz que a qualificação da matéria não é idêntica em seu direito e no direito estrangeiro, atenta-se para a qualificação em seu próprio direito, para depois verificar, diante da qualificação em seu próprio direito, se deve ou não se aplicar a lei estrangeira na hipótese.

Em matéria de testamentos, há exemplos interessantes. Uma situação emblemática é aquela do testamento conjuntivo, vedado pelas características essenciais do ato de última vontade, que é revogável, personalíssimo e unilateral, para preservar a espontaneidade da manifestação de última vontade. Ao qualificar a hipótese segundo a lei brasileira, poder-se-ia dizer que se trata de uma questão de forma, sendo certo que a matéria está disciplinada no artigo 1.863 do Código Civil, em capítulo intitulado Disposições Gerais das Formas Testamentárias. No entanto, há quem defenda se tratar de uma questão da substância do ato e, assim, não se aplicar ao caso o brocardo locus regit actum, uma vez que o testamento de mão comum violaria os preceitos de ordem pública no Brasil, que proíbem os pactos sucessórios e concebem o testamento de forma livre, espontânea e revogável. Dessa forma, mesmo se a lei reguladora da sucessão permitir o testamento conjuntivo, aqui no Brasil este não poderia ser executado por afrontar a ordem pública (VELOSO, 1993, p. 97-99).

Em sentido diverso pondera Daniela Vargas (2019, p. 118), aduzindo que residentes no Brasil não podem celebrar testamento conjuntivo no exterior, uma vez que a lei pessoal do testador (a brasileira) proíbe a prática. Já o brasileiro domiciliado em país onde o testamento conjuntivo é permitido terá plena capacidade de testar dessa forma, uma vez que a lei aplicável à sucessão não será a brasileira, aplicando-se o art. $9^{\circ}$ da LINBD.

Em decisão recente, o Tribunal de Justiça do Distrito Federal considerou válido um testamento conjuntivo lavrado no Brasil em virtude das peculiaridades do caso, a saber, testadores estrangeiros, erro do Tabelião e a inequívoca vontade de deixar os bens para a filha de criação. ${ }^{19} \mathrm{Em} \mathrm{2015}$, o Superior Tribunal de Justiça

\footnotetext{
19 Processual Civil. Sucessão. Registro E Cumprimento De Testamento. Jurisdição Voluntária. Testamento Conjuntivo. Vedação Legal. Código Civil De 1916. Vedação Repetida no Código Civil de 2012. Excepcionalidade da Situação Fática. Testadores Estrangeiros (Portugueses). Equivoco do Tabelião. Excesso de Formalismo. Aplicação do Juízo de Equidade. Possibilidade. Art. 1.109 Do CPC. Legalidade Estrita. Mitigação. Recurso Conhecido $E$ Improvido. 1. No caso dos autos, não há dúvidas de que o casal falecido, estrangeiros (portugueses) que residiam no Brasil, criaram a requerente, também portuguesa, como a filha que não tiveram. Também não resta nenhuma dúvida de que a intenção deles foi a de deixar o único bem que amealharam em vida para a filha de criação. Não há outros filhos, nem parentes conhecidos do casal falecido. 2 . In casu, não se pode desprezar, em razão do equivoco perpetrado pelo Tabelião - que lavrou as últimas vontades dos testadores em um único documento -, a intenção ali assentada, vez que os falecidos manifestaram inequívoco interesse em deixar seus bens (presentes e futuros), em favor da requerente/ apelada, sua filha de criação. 3. O argumento de que o testamento que aparelha os autos é conjuntivo, o que ensejaria, nos termos do art. 1.630 do CC/1916 (dispositivo repetido no art. 1.863 do CC/2002), sua nulidade; encerra excessivo apego ao formalismo, tendo em vista que, em razão da moldura fática apresentada nos autos, os bens deixados pelo casal falecido, em razão da ausência de ascendentes, descendentes e da inexistência de notícia de colaterais, serão entregues à Fazenda Pública. 4. Precedente: "[...] não se deve alimentar a superstição do formalismo obsoleto, que prejudica mais do que ajuda. embora as formas testamentárias operem como jus cogens, entretanto a lei da forma esta sujeita a interpretação e construção apropriadas as circunstâncias. Recurso conhecido, mas desprovido. (REsp 1422/rs, Rel. Ministro Gueiros Leite, Terceira Turma, julgado em 02/10/1990, DJ 04/03/1991, p. 1983)" 5. Ail. Magistrada de primeiro grau converteu o feito em Registro e Cumprimento de Testamento, conforme decisão interlocutória, portanto, de jurisdição voluntária. 6 . Em sendo assim, o juiz não está obrigado a decidir com base na legalidade estrita (art. 1.109, CPC), facultando-lhe, portanto, o juízo por equidade, ou seja, poderá adotar, no caso concreto, a solução que reputar mais conveniente ou oportuna. A doutrina entende que tal dispositivo reconhece a presença de certa discricionariedade do juiz. 7 . Recurso conhecido e improvido. Sentença mantida. TJ-DF - APC: 20110610113130 DF 0011120-70.2011.8.07.0006, Relator: Alfeu Machado, Julgado em 01/10/2014, $1^{\text {a }}$ Turma Cível, Data de Publicação: Publicado no DJE : 06/10/2014 . Pág.: 80.
} 
se pronunciou sobre um testamento conjuntivo, mas não se pode dizer que se posicionou sobre a matéria no referido acórdão, uma vez que o bem sobre o qual dito testamento dispôs estava situado na Alemanha, local onde o testamento foi realizado. ${ }^{20}$

Condição de herdeiro e ordem de vocação hereditária, substituição, direitos dos herdeiros ou dos legatários, validade e eficácia das disposições testamentárias, limites à liberdade de testar, colação, modo de partilha e dívidas são questões de substância da sucessão hereditária e, portanto, devem ser regidas pela lei do domicílio do autor da herança, como determinado pelo art. 10 da LINBD. No entanto, "a lei estrangeira aplicável à sucessão, em razão do domicílio do de cujus, precisará passar pelo crivo da ordem pública do país da situação dos bens para ser aplicável à partilha" (VARGAS, 2019, p. 104).

Questão interessante poderia ser aquela de previsões no Direito português, denominadas de substituição pupilar e quase-pupilar (Código Civil Português, art. $2.298^{\circ}$ ), que permite que o ascendente nomeie herdeiros ou legatários ao filho menor ou incapaz de testar, sendo certo que essa substituição só poderá abranger os bens que o substituído haja adquirido por via do testador, mesmo que por força de sucessão legítima (VELOSO, 2018, p. 373). De acordo com o Direito português, a substituição pupilar cessa logo que o substituído perfaça os dezoito anos, ou se falecer deixando descendentes ou ascendentes. Já a substituição quase-pupilar fica sem efeito logo que cesse a impossibilidade de testar ou se o substituído falecer deixando descendentes ou ascendentes. Sem dúvida, não são incomuns casos de pessoas que têm filhos impossibilitados de manifestar sua vontade testamentária e, assim, temem pelo destino do patrimônio que ditos filhos herdarão. Não raro, há divergências nas famílias e os herdeiros do filho com deficiência são justamente seus desafetos familiares.

20 Recurso especial. Direito Internacional Privado. Ação de sonegados promovida pelos netos da autora da herança (e alegadamente herdeiros por representação de seu pai, pré-morto) em face da filha sobrevivente da de cujus, reputada herdeira única por testamento cerrado e conjuntivo feito em 1943, em meio a Segunda Guerra mundial, na Alemanha, destinada a sobrepartilhar bem imóvel situado naquele país (ou o produto de sua venda). 1. Lei do domicílio do autor da herança para regular a correlata sucessão. Regra que comporta exceção. Existência de bens em estados diferentes. 2. Jurisdição brasileira. Não instauração. Impossibilidade de deliberar sobre bem situado no exterior. Adoção do princípio da pluralidade dos juízos sucessórios. 3. Existência de imóvel situado na Alemanha, bem como realização de testamento nesse país. Circunstâncias prevalentes a definir a lex rei sitae como a regente da sucessão relativa ao aludido bem. Aplicação. 4. Pretensão de sobrepartilhar o imóvel sito na Alemanha ou o produto de sua venda. Inadmissibilidade. Reconhecimento, pela lei e pelo poder judiciário alemão, da condição de herdeira única do bem. Incorporação ao seu patrimônio jurídico por direito próprio. Lei do domicilio do de cujus. Inaplicabilidade antes e depois do encerramento da sucessão relacionada ao imóvel situado no exterior. 5. Imputação de má-fé da inventariante. Insubsistência. 6 . Recurso Especial Improvido. 1. A lei de Introdução às Normas de Direito Brasileiro (LINDB) elegeu o domicílio como relevante regra de conexão para solver conflitos decorrentes de situações jurídicas relacionadas a mais de um sistema legal (conflitos de leis interespaciais), porquanto consistente na própria sede jurídica do indivíduo. Em que pese a prevalência da lei do domicílio do indivíduo para regular as suas relações jurídicas pessoais, conforme preceitua a LINDB, esta regra de conexão não é absoluta. 1.2 Especificamente à lei regente da sucessão, pode-se assentar, de igual modo, que o art. 10 da LINDB, ao estabelecer a lei do domicílio do autor da herança para regê-la, não assume caráter absoluto. A conformação do direito internacional privado exige a ponderação de outros elementos de conectividade que deverão, a depender da situação, prevalecer sobre a lei de domicílio do de cujus. $\mathrm{Na}$ espécie, destacam-se a situação da coisa e a própria vontade da autora da herança ao outorgar testamento, elegendo, quanto ao bem sito no exterior, reflexamente a lei de regência. 2. O art. 10, caput, da LINDB deve ser analisado e interpretado sistematicamente, em conjunto, portanto, com as demais normas internas que regulam o tema, em especial o art. $8^{\circ}$, caput, e $\S 1^{\circ}$ do art. 12 , ambos da LINDB e o art. 89 do CPC. E, o fazendo, verifica-se que, na hipótese de haver bens imóveis a inventariar situados, simultaneamente, aqui e no exterior, o Brasil adota o princípio da pluralidade dos juízos sucessórios. 2.1 Inserem-se, inarredavelmente, no espectro de relações afetas aos bens imóveis aquelas destinadas a sua transmissão/alienação, seja por ato entre vivos, seja causa mortis, cabendo, portanto, à lei do país em que situados regê-las (art. $8^{\circ}$, caput, LINDB). 2.2 A Jurisdição brasileira, com exclusão de qualquer outra, deve conhecer e julgar as ações relativas aos imóveis situados no país, assim como proceder ao inventário e partilha de bens situados no Brasil, independente do domicilio ou da nacionalidade do autor da herança (Art. 89 CPC e $\S 2^{\circ}$ do art. 12 da LINDB) 3. A existência de imóvel situado na Alemanha, bem como a realização de testamento nesse país são circunstâncias prevalentes a definir a lex rei sitae como a regente da sucessão relativa ao aludido bem (e somente a ele, ressalta-se), afastando-se, assim, a lei brasileira, de domicílio da autora da herança. Será, portanto, herdeiro do aludido imóvel quem a lei alemã disser que o é. E, segundo a decisão exarada pela Justiça alemã, em que se reconheceu a validade e eficácia do testamento efetuado pelo casal em 1943, durante a Segunda Guerra Mundial, a demandada é a única herdeira do imóvel situado naquele país (ante a verificação das circunstâncias ali referidas - morte dos testadores e de um dos filhos). 3.1 Esta decisão não tem qualquer repercussão na sucessão aberta - e concluída - no Brasil, relacionada ao patrimônio aqui situado. De igual modo, a jurisdição brasileira, porque também não instaurada, não pode proceder a qualquer deliberação quanto à extensão do que, na Alemanha, restou decidido sobre o imóvel lá situado. 4. O imóvel situado na Alemanha (ou posteriormente, o seu produto), de acordo com a lei de regência da correspondente sucessão, passou a integrar o patrimônio jurídico da única herdeira. A lei brasileira, de domicílio da autora da herança, não tem aplicação em relação à sucessão do referido bem, antes de sua consecução, e, muito menos, depois que o imóvel passou a compor a esfera jurídica da única herdeira. Assim, a providência judicial do juízo sucessório brasileiro de inventariar e sobrepartilhar o imóvel ou o produto de sua venda afigurar-se-ia inexistente, porquanto remanesceria não instaurada, de igual modo, a jurisdição nacional. E, por consectário, a pretensão de posterior compensação revela-se de todo descabida, porquanto significaria, em última análise, a aplicação indevida e indireta da própria lei brasileira. 5. O decreto expedido pelo Governo alemão, que viabilizara a restituição de bens confiscados aos proprietários que comprovassem a correspondente titularidade, é fato ocorrido muito tempo depois do encerramento da sucessão aberta no Brasil e que, por óbvio, refugiu, a toda evidência, da vontade e do domínio da inventariante. Desde 1983, a ré, em conjunto com os autores, envidou esforços para obter a restituição do bem. E, sendo direito próprio, já que o bem passou a integrar seu patrimônio jurídico, absolutamente descabido exigir qualquer iniciativa da ré em sobrepartilhar tal bem, ou o produto de sua venda. Do que ressai absolutamente infundada qualquer imputação de má-fé à pessoa da inventariante. 6. Recurso especial improvido. STJ - Resp: 1362400 SP 2012/0219242-9, Relator: Ministro Marco Aurélio Belizze, Julgado em 28/04/2015, T3, Data de Publicação: DJe 05/06/2015 vol. 960 p. 643 
Na hipótese de um testamento lavrado em Portugal com previsão de uma substituição quase-pupilar, sendo o filho com deficiência e o ascendente testador domiciliados em Portugal, poderia a referida previsão produzir efeitos no Brasil? Considerando que a lei aplicável à sucessão no Brasil seria a lei portuguesa e restando cabalmente comprovada a impossibilidade de o substituído testar, a resposta parece afirmativa. No entanto, trata-se de uma questão tormentosa em virtude das características do testamento, que é ato personalíssimo e unilateral.

Uma última palavra deve ser dita em relação ao disposto no art. $10, \S 2^{\circ}$, da LINDB, que dispõe que a lei do domicílio do herdeiro ou legatário regula a capacidade para suceder. O dispositivo em referência não está relacionado com a condição de herdeiro ou legatário, uma vez que esta é definida pela lei aplicável à sucessão. Trata o artigo em comento da capacidade para suceder. Assim, questões atinentes à indignidade, por exemplo, serão reguladas pela lei do domicílio do herdeiro ou legatário, o mesmo se passando para a hipótese de herdeiros submetidos ao regime de curatela, que precisarão observar a legislação do país de seu domicílio quanto à extensão dos poderes concedidos ao curador diante da herança a ser recebida. No Brasil, por exemplo, segundo dispõe o art. 1.748, II, compete ao curador, com autorização do juiz, aceitar heranças, legados ou doações pelo curatelado. Assim, havendo uma sucessão no exterior com herdeiro curatelado domiciliado no Brasil, a aceitação da herança, praticada pelo curatelado por meio de seu curador, dependerá de autorização judicial.

\section{Conclusão}

Diante da circulação cada vez maior de pessoas e bens pelo mundo, as sucessões hereditárias com elementos internacionais são cada vez mais frequentes. Nessa direção, crescem em importância os acordos internacionais, através dos quais os Estados podem estabelecer obrigações recíprocas, adotando com o devido critério instrumentos para a cooperação jurídica internacional, entendida esta como "o intercâmbio internacional para o cumprimento extraterritorial de medidas processuais provenientes do Judiciário de um Estado estrangeiro" (ARAUJO, 2018, p. 218).

Foi o que ocorreu na Europa, com a entrada em vigor em agosto de 2015 do Regulamento (UE) n 650/2012 sobre sucessões, que visa facilitar as transmissões sucessórias transnacionais na Europa, que se tornaram cada vez mais frequentes com a União Europeia. Assim, embora dito regulamento não tenha eliminado os processos de reconhecimento e de exequatur das decisões proferidas pelos Estados-membros, dita legislação visa garantir a coerência no momento da transmissão hereditária, sendo aplicada a uma sucessão transnacional uma única lei, por uma única autoridade. O dito regulamento prevê como regra geral para regular a sucessão a lei do Estado em que o falecido tinha residência habitual no momento do óbito, permitindo que o autor da herança escolha a lei que deve regular a sua sucessão, podendo optar entre a lei de que é nacional no momento em que faz a escolha ou no momento do óbito, sendo certo que uma pessoa com nacionalidade múltipla poderá escolher a lei de qualquer dos Estados de que é nacional no momento em que faz a escolha.

Sem dúvida, acordos como o explicitado apresentam maior segurança jurídica e previsibilidade das decisões, estreitando as relações entre países, podendo ser bilaterais ou multilaterais, admitindo-se, assim, por via de prévia disposição analisada pelo Estado, uma mitigação de sua competência exclusiva em prol da coerência da sucessão hereditária, ou seja, em prol da aplicação de uma decisão única a todos os bens deixados pelo falecido, onde quer que se encontrem, por uma única autoridade competente.

\section{Referências}

ARAÚJO, Nádia de. Direito internacional privado: teoria e prática. 7. ed. São Paulo: Revista dos Tribunais, 2018.

BRASIL. [Constituição (1988)]. Constituição da República Federativa do Brasil de 1988. Brasília, DF: Presidência da República, [2016]. Disponível em: http://www.planalto.gov.br/ccivil_03/Constituicao/ Constituiçao.htm. Acesso em: 1 jan. 2019. 
COLUCCI, Nycolas Martins. Incidência do ITCMD na sucessão de bens móveis, títulos e créditos decorrente de inventário processado no exterior. Revista dos Tribunais, São Paulo, v. 22, n. 116, p. 203-213, 2014.

DOLINGER, Jacob. Direito internacional privado: parte geral. 11. ed. Rio de Janeiro: Forense, 2014. MADALENO, Rolf. Inventário de bens situados no exterior e a sua compensação para efeito de equilíbrio dos quinhões. Revista Brasileira de Direito de Família, Porto Alegre, v. 7, n. 29, p. 223-234, 2005.

MARTINS, Ives Gandra da Silva. Necessidade de lei complementar para a conformação do imposto de transmissão causa mortis e por doação de bens e recursos recebidos do exterior - inteligência do art. 155, §1, III, da CF - opinião geral. Revista dos Tribunais, São Paulo, v. 93, n. 821, p. 115-127, 2004. MEINERO, Fernando Pedro. Sucessões internacionais no Brasil. Curitiba: Juruá, 2017.

OLIVEIRA, Euclides de; AMORIM, Sebastião. Inventário e partilha: teoria e prática. São Paulo: Saraiva, 2016.

RAMOS, André de Carvalho. O direito internacional privado das sucessões no Brasil. Rev. Secr. Trib. Perm. Revis., año 4, n. 7, p. 307-324, Mayo 2016.

VALLADÃO, Haroldo. Unidade ou pluralidade da sucessão e do inventário e partilha, no direito internacional privado. Revista dos Tribunais, São Paulo, v. 93, n. 830, p. 717-746, 2004.

VARGAS, Daniela T. Patrimônio internacional e sucessões: Perspectiva do direito brasileiro. In: TEIXEIRA, Daniele Chaves. Arquitetura do planejamento sucessório. Belo Horizonte: Fórum, 2019. p. 101-124.

VELOSO, Zeno. Substituição quase-pupilar - deve ser introduzida no Direito Brasileiro. In: PEREIRA, Rodrigo da Cunha; DIAS, Maria Berenice (coord.). Famílias e sucessões: polêmicas, tendências e inovações. Belo Horizonte: IBDFAM, 2018. p. 369-378.

VELOSO, Zeno. Testamentos. 2. ed. Belém: Edições Cejup, 1993.

Recebido em: 03/03/2019

Aprovado em: 13/06/2019 